\title{
Antioxidant activity and mechanism of Rhizoma Cimicifugae
}

Xican $\mathrm{Li}^{1 *+}$, Jing Lin ${ }^{1 \dagger}$, Yaoxiang Gao ${ }^{1}$, Weijuan $\operatorname{Han}^{1}$ and Dongfeng Chen ${ }^{2 *}$

\begin{abstract}
Background: As a typical Chinese herbal medicine, rhizoma Cimicifugae (RC, 升麻 in Chinese) possesses various pharmacological effects involved in antioxidant activity. However, its antioxidant activity has not been reported so far. The aim of the present study was to systematically evaluate the antioxidant ability of RC in vitro, then discuss the mechanism.

Methods: Firstly, five RC extracts (i.e. petroleum ether extract PERC, ethyl acetate extract EARC, absolute ethanol extract AERC, 95\% ethanol extract 95ERC, and water extract WRC) were prepared and determined by various antioxidant methods, including anti-lipidperoxidation, protection against DNA damage, $\cdot \mathrm{OH}$ scavenging, $\cdot \mathrm{O}_{2}^{-}$ scavenging, DPPH• (1,1-diphenyl-2-picryl-hydrazl radical) scavenging, $\mathrm{ABTS}^{+} \cdot\left(2,2^{\prime}\right.$-azino-bis (3-ethylbenzothiazoline-6-sulfonic acid radical ion) scavenging, $\mathrm{Cu}^{2+}$-chelating, and $\mathrm{Fe}^{3+}$ reducing assays. Subsequently, we measured the chemical contents of five RC extracts, including total phenolics, total saponins, total sugars, caffeic acid, ferulic acid and isoferulic acid. Finally, we quantitatively analyzed the correlations between antioxidant levels $\left(1 / \mathrm{C}_{50}\right.$ values $)$ and chemical contents.

Results: In the study, the antioxidant levels and chemical contents (including total phenolics, total saponins, total sugars, caffeic acid, ferulic acid and isoferulic acid) of five RC extracts were determined by various methods. In all antioxidant assays, five RC extracts increased the antioxidant levels in a dose-dependent manner. However, their antioxidant levels ( $\left(C_{50}\right.$ values) and chemical contents significantly differed from each other. Quantitative analysis of the correlation showed that total phenolic was of significant positive correlations (average $R$ value was 0.56 ) with antioxidant levels; In contrast, total sugars and total saponins had no positive correlation with antioxidant (the average $R$ values were -0.20 and -0.26 , for total sugars and total saponins, respectively); Among total phenolics, three phenolic acids (caffeic acid, ferulic acid and isoferulic acid) also displayed positive correlations (the average $\mathrm{R}$ values were $0.51,0.50$, and 0.51 , for caffeic acid, ferulic acid and isoferulic acid, respectively).

Conclusions: As an effective antioxidant, Rhizoma Cimicifugae can protect DNA and lipids against oxidative damage. Its antioxidant ability can be responsible for its various pharmacological effects and may be mainly attributed to the existence of total phenolics, among which caffeic acid, ferulic acid and isoferulic acid are regarded as main bioactive components. Rhizoma Cimicifugae exerts its antioxidant effect through metal-chelating, and radical-scavenging which is via donating hydrogen atom $(\mathrm{H} \cdot$ ) and donating electron (e).
\end{abstract}

Keywords: Rhizoma Cimicifugae, 升麻, Antioxidant activity, Metal chelating, Radical-scavenging, Phenolic acid

\footnotetext{
* Correspondence: lixican@126.com; cdf27212@21cn.com

${ }^{\dagger}$ Equal contributors

${ }^{1}$ School of Chinese Herbal Medicine, Guangzhou Higher Education Mega

Center, Guangzhou University of Chinese Medicine, Waihuang East Road

No.232, Guangzhou 510006, China

${ }^{2}$ School of Basic Medical Science, Guangzhou University of Chinese Medicine,

Guangzhou 510006, China
}

\section{() Chemistry Central}

(c) 2012 Li et al.; licensee Chemistry Central Ltd. This is an Open Access article distributed under the terms of the Creative Commons Attribution License (http://creativecommons.org/licenses/by/2.0), which permits unrestricted use, distribution, and reproduction in any medium, provided the original work is properly cited. 


\section{Background}

As we know, reactive oxygen species (ROS) are various forms of activated oxygen including free radicals and non-free-radical species. ROS can oxidatively damage vital cellular structures such as lipids and DNA [1,2], then lead to severe biological consequences including mutation, cell death, carcinogenesis, and aging [3].

Therefore, it is important to search for potential therapeutic agents for oxidative damage. In recent years, medicinal plants especially Chinese medicinal herbals have attracted much attention.

As a typical Chinese herbal medicine, rhizoma Cimicifugae (RC, 升麻 in Chinese, the photo is shown in Additional file 1) has been used for over 2000 years [4]. From the viewpoint of tradition Chinese medicine (TCM), RC can elevate yang, lift qi, clear heat, remove toxic, induce sweats to dispel exopathogens, and promote eruption [5].

Modern medicine indicated that $\mathrm{RC}$ possessed various pharmacological effects. Ye reported that RC possessed antidepressant-like properties in rodents [6]; Kim pointed out that RC can treat pain and inflammation [7]; An isopropanolic extract of $\mathrm{RC}$, however, was proved to be able to diminish the urinary content of PYR and DPY and the morphometric correlates of bone loss associated with ovariectomy in rats [8]; The supply of RC can therefore prevent OVX-induced bone loss in mice [9]. In addition, the extract of RC was found to have protective effect against gastric injury [10]. According to free radical biology \& medicine [11], these pharmacological effects are related to antioxidant ability. However, its antioxidant ability has not been explored so far.

Therefore, the aim of the study was to investigate the antioxidant ability of RC in vitro, then further discuss the antioxidant mechanism.

\section{Results and discussion}

As an important biomolecule, lipid can be easily attacked by ROS to generate lipid peroxidation which is harmful to cell. For example, the highly reactive $\cdot \mathrm{OH}$ radical can attack to lipid to produce lipidperoxidation (Equations 1-3):

$$
\begin{aligned}
& \text { Lipid }-\mathrm{H}+\bullet \mathrm{OH} \rightarrow \text { Lipid } \bullet+\mathrm{H}_{2} \mathrm{O} \\
& \text { Lipid } \bullet+\mathrm{O}_{2} \rightarrow \text { Lipid }-\mathrm{O}_{2} \bullet \\
& \text { Lipid }-\mathrm{H}+\text { Lipid }-\mathrm{O}_{2}^{\bullet} \rightarrow \text { Lipid }-\mathrm{O}_{2} \mathrm{H}+\text { Lipid }
\end{aligned}
$$

In our study, five RC extracts increased the antilipidperoxidation percentages in a dose-dependent manner (Additional file 2). It means that five RC extracts can effectively protect lipid against oxidative damage. Among them, EARC possessed the highest anti-lipidperoxidation activity (Table 1).
Besides lipid, another biomolecule DNA can also be oxidatively damaged by ROS (especially $\bullet \mathrm{OH}$ ). It is well known that DNA consists of deoxyribose, organic phosphate and various base pairs. When DNA is attacked by $\cdot \mathrm{OH}$ radical, MDA (malondialdehyde) and a number of oxidative lesions are generated [12]. MDA combines with 2-thiobarbituric acid (TBA) to produce thiobarbituric acid-reactive substances (TBARS) with $\lambda_{\max }$ at $530 \mathrm{~nm}$ (Scheme 1).

Therefore, the $A_{532 n m}$ value is proportional to the produced amount of $\bullet \mathrm{OH}$ radicals. Higher $\mathrm{A}_{532 \mathrm{~nm}}$ values indicate higher levels of $\bullet \mathrm{OH}$ radicals. If an antioxidant sample is added, the $A_{532 \mathrm{~nm}}$ value will decrease, suggesting that some $\cdot \mathrm{OH}$ radicals are scavenged and the hydroxylinduced DNA damage are protected by the antioxidant.

Among five RC extracts, 95ERC and EARC were proved to be of protective effect against hydroxyl-induced DNA damage (Table 1 and Additional file 2).

Previous studies have shown that there are two approaches for natural phenolic antioxidant to protect DNA oxidative damage: one is to scavenge the $\cdot \mathrm{OH}$ radicals then to reduce its attack; one is to fast repair the deoxynucleotide radical cations resulting from $\bullet \mathrm{OH}$ radicals attack [11]. In order to further confirm whether the protective effect against DNA oxidative damage was relevant to radical-scavenging ability, the . $\mathrm{OH}$ and. $\mathrm{O}_{2}^{-}$radical-scavenging abilities of five $\mathrm{RC}$ extracts was determined in vitro.

As we know, $\bullet \mathrm{OH}$ radical in body is produced by Fenton reaction (Equation 4). However, our data suggested that five $\mathrm{RC}$ extracts can effectively scavenge $\cdot \mathrm{OH}$ radicals (Table 1 and Additional file 2).

$$
\mathrm{Fe}^{2+}+\mathrm{H}_{2} \mathrm{O}_{2} \rightarrow \bullet \mathrm{OH}+\mathrm{OH}^{-}+\mathrm{Fe}^{3+}
$$

Besides $\cdot \mathrm{OH}$ radical, superoxide anion radical $\left(\cdot \mathrm{O}_{2}^{-}\right)$is also regarded as one important form of ROS in living cell. It can directly attack DNA or lipid [13], and can transferred into $\bullet \mathrm{OH}$ via Haber-Weiss reaction (Equation 5) to indirectly damage DNA or lipid as well [2]. The results in Table 1 and Additional file 2 showed that five RC extracts could also scavenge $\bullet \mathrm{O}_{2}^{-}$radicals.

$$
\cdot \mathrm{O}_{2}^{-}+\mathrm{H}_{2} \mathrm{O}_{2} \stackrel{\text { Iron ion }}{\rightarrow} \cdot \mathrm{OH}+\mathrm{OH}^{-}+\mathrm{O}_{2}
$$

Taken together, the protective effect of RC against hydroxyl-induced DNA oxidative damage can be assumed to be relevant to the $\cdot \mathrm{OH}$ or $\bullet_{2}^{-}$radical-scavenging ability.

However, as illustrated in Equations 4 and 5, the generations of $\bullet \mathrm{OH}$ and $\cdot \mathrm{O}_{2}^{-}$radicals rely usually on the catalysis of transition metals (especially $\mathrm{Fe}$ and $\mathrm{Cu}$ ). So we further explored the metal chelating abilities of five RC extracts. The dose-response curves showed that five RC extracts possessed effective metal chelating abilities (Additional file 2). Our previous reports have shown that 
Table 1 The $\mathrm{IC}_{50}$ values of five RC extracts and the positive controls $(\mu \mathrm{g} / \mathrm{mL})$

\begin{tabular}{|c|c|c|c|c|c|c|}
\hline Assays & PERC & EARC & AERC & 95ERC & WRC & GSH \\
\hline Anti-lipid peroxidation & $13.99 \pm 2.11^{\mathrm{e}}$ & $4.55 \pm 0.44^{b}$ & $14.92 \pm 4.31^{d}$ & $10.62 \pm 0.97^{c}$ & $19.18 \pm 2.04^{f}$ & $0.028 \pm 0.00^{a} *$ \\
\hline DNA protective effect & - & $1905.51 \pm 177.54^{c}$ & $14397.18 \pm 1075.01^{d}$ & $1090.11 \pm 21.25^{b}$ & - & $114.42 \pm 2.66^{a * *}$ \\
\hline$\cdot \mathrm{OH}$ & $561.19 \pm 21.16^{f}$ & $111.55 \pm 1.32^{c}$ & $132.32 \pm 0.15^{d}$ & $84.30 \pm 1.02^{b}$ & $233.45 \pm 15.70^{e}$ & $37.67 \pm 0.67^{\mathrm{a} * *}$ \\
\hline$\cdot \mathrm{O}_{2}^{-}$ & $322.81 \pm 14.90^{b}$ & $306.68 \pm 0.87^{b}$ & $284.36 \pm 11.43^{b}$ & $301.08 \pm 8.34^{b}$ & $650.65 \pm 59.55^{c}$ & $81.65 \pm 5.21^{\mathrm{a}}$ \\
\hline Chelating & $191.86 \pm 1.84^{b}$ & $319.20 \pm 6.36^{c}$ & $872.71 \pm 30.63^{e}$ & $553.34 \pm 12.59^{d}$ & $2289.11 \pm 100.00^{f}$ & $107.86 \pm 0.31^{a * * *}$ \\
\hline DPPH• & $813.00 \pm 225.17^{d}$ & $227.09 \pm 10.14^{b}$ & $260.34 \pm 11.37^{c}$ & $254.73 \pm 4.33^{c}$ & $229.17 \pm 5.81^{b}$ & $5.13 \pm 1.19^{a * *}$ \\
\hline ABTS..$^{+}$ & $395.65 \pm 77.34^{\mathrm{e}}$ & $72.10 \pm 1.32^{b}$ & $96.39 \pm 1.12^{d}$ & $94.38 \pm 2.45^{d}$ & $83.58 \pm 0.81^{c}$ & $4.76 \pm 0.28^{a}$ \\
\hline $\mathrm{Fe}^{3+}$ reducing & $533.12 \pm 54.25^{e}$ & $159.35 \pm 1.37^{b}$ & $317.06 \pm 3.47^{c}$ & $156.19 \pm 2.12^{b}$ & $488.75 \pm 18.60^{d}$ & $51.89 \pm 1.29^{a}$ \\
\hline
\end{tabular}

$\mathrm{IC}_{50}$ value is defined as the concentration of $50 \%$ effect percentage and calculated by linear regression analysis and expressed as mean \pm SD ( $n=3$ ). The linear regression was analyzed by Origin 6.0 professional software. Means values with different superscripts in the same row are significantly different $(p<0.05)$, while with same superscripts are not significantly different $(p<0.05)$. *The positive control was BHA, instead of GSH. ** The positive control was Trolox, instead of GSH. *** The positive control was Sodium citrate. Results were analyzed by independent samples. PERC, petroleum ether extract of rhizoma Cimicifugae; EARC, ethyl acetate extract of rhizoma Cimicifugae; AERC, absolute ethanol extract of rhizoma Cimicifugae; 95ERC, 95\% ethanol extract of rhizoma Cimicifugae; WRC, water extract of rhizoma Cimicifugae. -: Cannot be detected.

the chelating ability might be mainly attributed to ortho dihydroxyl groups in phenolic compounds [14]. For example, phenolic acids can bind $\mathrm{Fe}^{2+}$ as the following mechanism (Scheme 2) [15].

The fact that five $\mathrm{RC}$ extracts can effectively bind $\mathrm{Fe}^{2+}$ ion, suggests that metal-chelating may be one of mechanisms for scavenging $\bullet \mathrm{OH}$ or $\bullet \mathrm{O}_{2}^{-}$.

In order to verify whether five $\mathrm{RC}$ extracts can directly scavenge radicals. We determined their $\mathrm{DPPH}$ • and ABTS $\bullet^{+}$radical-scavenging abilities.

As seen in Table 1 and Additional file 2, five $\mathrm{RC}$ extracts scavenged both $\mathrm{DPPH} \bullet$ and $\mathrm{ABTS} \bullet^{+}$radicals in a dose-dependent manner. The previous studies have demonstrated that $\mathrm{DPPH}$ - may be scavenged by an antioxidant through donation of hydrogen atom $(\mathrm{H} \cdot)$ to form a stable DPPH-H molecule [16-18]. Caffeic acid, a phenolic acid occurring in $\mathrm{RC}$, for example, could scavenge $\mathrm{DPPH}$ • via the proposed reaction (Scheme 3) [19].

Radical (A) can be further withdrawn hydrogen atom (H•) to form stable quinone (B) (Scheme 4).

Unlike DPPH• scavenging, ABTS $\bullet^{+}$scavenging however is considered as an electron (e) transfer reaction [20]. For example, the proposed reaction for caffeic acid to scavenge ABTS $~^{+}$can be briefly illustrated using Scheme 5. Similarly, if ABTS ${ }^{+}$is excessive, radical (A) can also further change to quinone (B).
As illustrated in Scheme 3, 4 and 5, the generations of both DPPH. and ABTS ${ }^{+}$radicals did not rely on the transition metal catalysis.

Based on the discussion above, it can be deduced that direct radical-scavenging was regarded as another mechanism for five $\mathrm{RC}$ extract to scavenge $\bullet \mathrm{OH}$ or $\bullet \mathrm{O}_{2}^{-}$, and they exerted radical-scavenging action by donating hydrogen atom $(\mathrm{H} \cdot)$ and electron (e).

Until now, about 200 compounds have been found in RC [21]. Generally, they belong to three different classes, i.e. phenolics, saponins, and polysaccharides. In the study, we used chemical method to measure the contents of total phenolics, total saponins, and total sugars in fiver RC extracts (Table 2). On the other hand, since $1 / \mathrm{IC}_{50}$ value showed parallelism with antioxidant level, it was therefore used to evaluate antioxidant level in the study (Additional file 2). On this basis, forty-eight correlation graphs were plotted to quantitative analyze the correlation between antioxidant levels and chemical contents in five $\mathrm{RC}$ extracts (Additional file 3). The correlation coefficients ( $R$ values) in Table 3 indicated that, total phenolics were of significant positive correlations ( $\mathrm{R}=0.17 \sim 0.99$; average, 0.56$)$ with antioxidant levels, while total sugars and total saponins had no positive correlations (for total sugars, $\mathrm{R}=-0.88 \sim 0.46$, the average was -0.20 ; for total saponins, $\mathrm{R}=-0.92 \sim 0.94$, the average

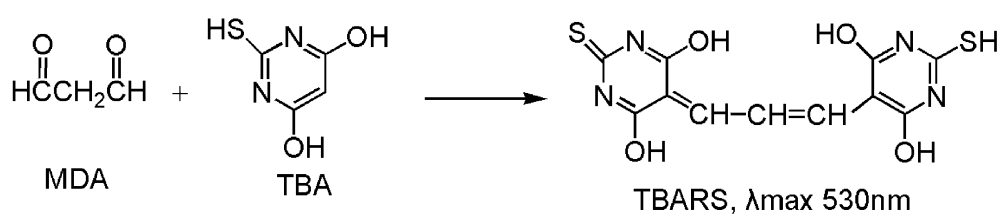

Scheme 1 The reaction of MDA (malondialdehyde) and 2-thiobarbituric acid (TBA). 
<smiles>[R]Oc1ccc(/C=C/C(=O)O)cc1Op1[Y13]([R])c2ccc(/C=C/C(=O)O)cc21</smiles>

$M=F e$ or $\mathrm{Cu} ; \mathrm{R}=\mathrm{R}^{\prime}=\mathrm{H}$, caffeic acid;

$\mathrm{R}=\mathrm{H}, \mathrm{R}^{\prime}=\mathrm{CH}_{3}$, ferulic acid; $\mathrm{R}=\mathrm{CH}_{3}, \mathrm{R}^{\prime}=\mathrm{H}$, isoferulic acid

Scheme 2 The proposal reaction of phenolic acids binding $\mathrm{Fe}^{2+}$.

was -0.26) with antioxidant levels. The data clearly demonstrated the significant contribution of phenolic compounds to the antioxidant of RC.

Among total phenolics, several compounds had been isolated from RC, including salicylic acid, caffeic acid, ferulic acid, isoferulic acid, flavonoids and tannins. In our study, however, three phenolic acids caffeic acid, ferulic acid and isoferulic acid were also identified by HPLC assay (Figure 1 and Additional file 4), in which peak areas were used to characterize the relative contents of three phenolic acids.

Then, we used the peak areas to plot the correlation graphs vs $1 / \mathrm{IC}_{50}$ values of five $\mathrm{RC}$ extracts, to obtain the correlation coefficients ( $\mathrm{R}$ values). As shown in Additional file 5 and Table 3, three phenolic acids all presented significant positive correlations (average $R$ value $=0.47,0.44$, and 0.51 , respectively for caffeic acid, ferulic acid and isoferulic acid). On the other hand, previous works have shown that three phenolic acids possess strong antioxidant ability [22-24]. Hence, they are considered as three of main bioactive compounds relevant to antioxidant in $\mathrm{RC}$.

\section{Experimental}

\section{Chemicals and plant material}

Trolox ( \pm -6-hydroxyl-2,5,7,8-tetramethlyhromane-2carboxylic acid), Ferrozin [3-(2-pyridyl)-5,6-bis (4-phenylsulfonicacid)-1,2,4-triazine], DPPH · (1,1-Diphenyl- 2-picrylhydrazyl radical), pyrogallol, linoleic acid, BHT (2.6-ditertiary butyl-p-cresol) and murexide (5,5' -Nitrilodibarbituric acid monoammonium salt) were purchased from Sigma Co. (Sigmaaldrich Trading Co., Shanghai, China); ABTS diammonium salt [2,2'-Azinobis (3-ethylbenzothiazoline-6-sulfonic acid diammonium salt)], D-2-deoxyribose, and GSH (glutathione) were Amresco Inc. (Solon, OH, USA); DNA sodium salt (fish sperm) was purchased from Aladdin Chemistry Co. (Shanghai, China); Ferulic acid, caffeic acid were purchased from National Institute for the Control of Pharmaceutical and Biological Products (Beijing, China); Acetonitrile, methanol and water were of HPLC grade; All other chemicals used were in analytical grade.

Rhizoma Cimicifugae was purchased from Guangzhou University of Chinese Medicine Yanghe Interlink Limited Company and identified by Prof. Shuhui Tan. A voucher specimen was deposited in our laboratory.

\section{Preparation of different extracts of rhizoma Cimicifugae}

The dried rhizoma Cimicifugae was coarsely powder then extracted in sequence with petroleum ether (60-90), ethyl acetate, ethanol, $95 \%$ ethanol and water by Soxhlet extractor for 12 hours. The extracts were concentrated under reduced pressure to a constant weight. Then the dried extracts were stored at $4^{\circ} \mathrm{C}$ until used (Figure 2).

\section{Protective effect against lipid-peroxidation}

The protective effect against lipid-peroxidation was investigated using a linoleic acid emulsion [25]. The linoleic acid emulsion was prepared by mixing and homogenizing $312.6 \mathrm{mg}$ of linoleic acid, $78.2 \mathrm{mg}$ of Tween20 as emulsifier, and $30 \mathrm{~mL}$ of $75 \%$ ethanol $(\mathrm{v} / \mathrm{v}), 0.1 \mathrm{~mL}$ of various concentrations of samples $(0.4-2.8 \mathrm{mg} / \mathrm{mL})$ were added to $1.5 \mathrm{~mL}$ of linoleic acid emulsion and $0.4 \mathrm{~mL}$ distilled water. The reaction mixture $(2 \mathrm{~mL})$ was incubated at room temperature in glass bottles for 72 hours. To $0.15 \mathrm{~mL}$ of sample solution, $3.65 \mathrm{~mL}$ of $75 \%$ ethanol, $0.1 \mathrm{~mL}$ of ammonium thiocyanate $(30 \%, \mathrm{~m} / \mathrm{v})$, and $0.1 \mathrm{~mL}$ of ferrous chloride $(0.02 \mathrm{M}$ in $3.6 \% \mathrm{HCl})$ were<smiles>O=[N+]([O-])c1cc([N+](=O)[O-])c(NN(c2ccccc2)c2ccccc2)c([N+](=O)[O-])c1</smiles>

$\mathrm{DPPH} \bullet$

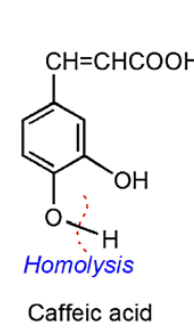<smiles>O=[N+]([O-])c1cc([N+](=O)[O-])c(NN(c2ccccc2)c2ccccc2)c([N+](=O)[O-])c1</smiles><smiles>O=C(O)/C=C/c1ccc(O)c(O)c1</smiles>

(A)

Scheme 3 The proposal reaction of caffeic acid to scavenge DPPH• (step 1). 


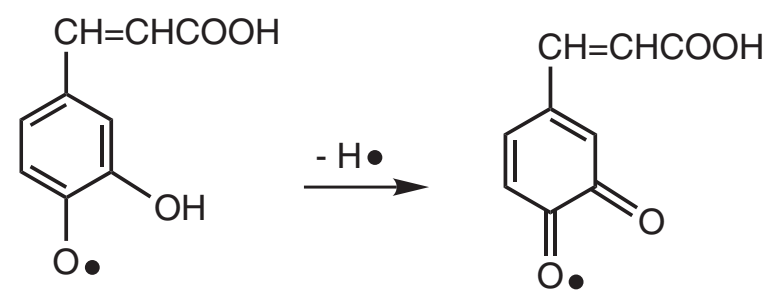

(A)

(B)

Scheme 4 The proposal reaction of caffeic acid to scavenge $\mathrm{DPPH} \bullet$ (step 2).

added. The mixture was diluted to two-fold volume with methanol in case the color was too dark, the peroxide value was measured by monitoring absorbance at $500 \mathrm{~nm}$ in a spectrophotometer (Unico 2100, Shanghai, China). The percentage of inhibition of lipid-peroxidation in linoleic acid emulsion was calculated by following equation:

$$
\text { Inhibition } \%=\frac{A_{0}-A}{A_{0}} \times 100 \%
$$

Where $A$ is the absorbance with samples, while $A_{0}$ is the absorbance without samples.

\section{Protective effect against hydroxyl-induced DNA damage}

The experiment was conducted as described in previous report [26]. However, deoxyribose was replaced by DNA sodium salt. Briefly, sample was dissolved in methanol to prepare the sample solution. Various amounts $(10-100 \mu \mathrm{L})$ of sample solutions $(10 \mathrm{mg} / \mathrm{mL})$ were then separately taken into mini tubes. After evaporating the sample solution in tube to dryness, $400 \mu \mathrm{L}$ phosphate buffer $(0.2 \mathrm{M}, \mathrm{pH}$ 7.4) was brought to the sample residue. Then, $50 \mu \mathrm{L}$ DNA (10.0 mg/mL), $75 \mu \mathrm{L} \mathrm{H} \mathrm{H}_{2} \mathrm{O}_{2}(33.6 \mathrm{mM}), 50 \mu \mathrm{L} \mathrm{FeCl}_{3}$ $(0.3 \mathrm{mM})$ and $100 \mu \mathrm{L} \mathrm{Na} a_{2}$ EDTA solutions $(0.5 \mathrm{mM})$ were added. The reaction was initiated by mixing $75 \mu \mathrm{L}$ ascorbic acid $(1.2 \mathrm{mM})$. After incubation in a water bath at $55^{\circ} \mathrm{C}$ for $20 \mathrm{~min}$, the reaction was terminated by $250 \mu \mathrm{L}$ trichloroacetic acid $(0.6 \mathrm{M})$. The color was then developed by addition of $150 \mu \mathrm{L}$ 2-thiobarbituric acid (TBA) $(0.4 \mathrm{M}$, in $1.25 \% \mathrm{NaOH}$ aqueous solution) and heated in an oven at $105^{\circ} \mathrm{C}$ for $15 \mathrm{~min}$. The mixture was cooled and absorbance was measured at $530 \mathrm{~nm}$ against the buffer (as blank). The percent of protection of DNA is expressed as follows:

$$
\text { Protective effect } \%=\frac{A_{0}-A}{A_{0}} \times 100 \%
$$

Where $A$ is the absorbance with samples, while $A_{O}$ is the absorbance without samples.

\section{Hydroxyl $(\cdot \mathrm{OH})$ radical-scavenging assay}

The hydroxyl radical-scavenging activity was investigated by the deoxyribose degradation method [26], with some modifications. In brief, the sample was dissolved in methanol, and then the sample solution was aliquoted into mini tubes. After evaporating the sample solutions in the tubes to dryness $(48-240 \mu \mathrm{g}), 300 \mu \mathrm{L}$ of phosphate buffer $(0.2 \mathrm{M}, \mathrm{pH} 7.4)$ was added to the sample residue. Subsequently, $50 \mu \mathrm{L}$ deoxyribose $(2.8 \mathrm{mM})$, $50 \mu \mathrm{L} \mathrm{H}_{2} \mathrm{O}_{2}(2.8 \mathrm{mM}), 50 \mu \mathrm{L} \mathrm{FeCl}_{3}(25 \mu \mathrm{M})$, and $100 \mu \mathrm{L}$ $\mathrm{Na}_{2}$ EDTA $(0.8 \mathrm{mM})$ were added. The reaction was initiated by mixing $50 \mu \mathrm{L}$ ascorbic acid $(1.2 \mathrm{mM})$ and the total volume of the reaction mixture was adjusted to $600 \mu \mathrm{L}$ with buffer. After incubation in a water bath at $50^{\circ} \mathrm{C}$ for $20 \mathrm{~min}$, the reaction was terminated by addition of $500 \mu \mathrm{L}$ trichloroacetic acid $(5 \%, \mathrm{w} / \mathrm{w})$. The color was then developed by addition of $500 \mu \mathrm{L}$ TBA $(1 \mathrm{~g} / 100 \mathrm{~mL}$, in $1.25 \% \mathrm{NaOH}$ aqueous solution) and heated in an oven at $105^{\circ} \mathrm{C}$ for $15 \mathrm{~min}$. The mixture was cooled and the absorbance was measured at $532 \mathrm{~nm}$ against the buffer (as a blank control). The inhibition percentage for $\bullet \mathrm{OH}$ was expressed as follows:

$$
\text { Inhibition } \%=\frac{A_{0}-A}{A_{0}} \times 100 \%
$$

Where $A$ is the absorbance containing samples, while $A_{O}$ is the absorbance without samples.

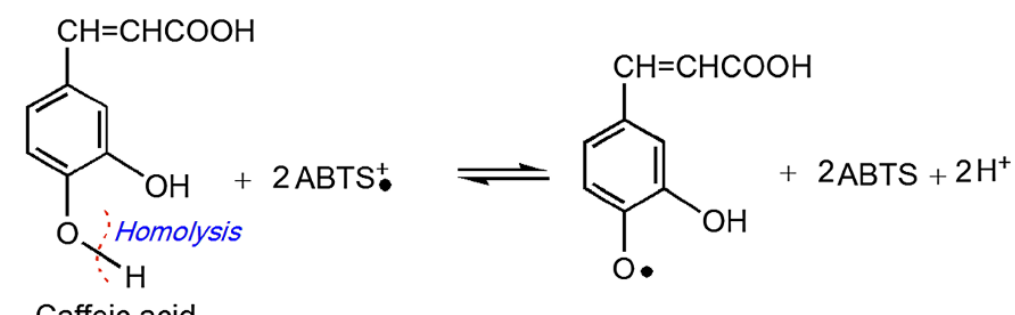

Caffeic acid 
Table 2 Chemical contents of five RC extracts

\begin{tabular}{|c|c|c|c|c|c|}
\hline Extracts & PERC & EARC & AERC & 95ERC & WRC \\
\hline Total phenolics (mg Pyr./g) & $13.17 \pm 0.43^{\mathrm{a}}$ & $65.01 \pm 0.34^{d}$ & $15.73 \pm 0.34^{b}$ & $31.10 \pm 1.30^{c}$ & $12.46 \pm 1.00^{a}$ \\
\hline Total sugars (mg Glucose/g) & $237.16 \pm 38.67^{a}$ & $175.46 \pm 21.50^{a}$ & $624.75 \pm 17.62^{b}$ & $603.48 \pm 18.74^{b}$ & $804.54 \pm 50.53^{c}$ \\
\hline Total saponins (mg Ole./g) & $917.52 \pm 87.83^{c}$ & $379.46 \pm 15.46^{b}$ & $185.16 \pm 4.10^{\mathrm{a}}$ & $180.44 \pm 1.95^{\mathrm{a}}$ & $198.34 \pm 12.30^{a}$ \\
\hline Caffeic acid (peak area) & $2.96 \pm 0.85^{\mathrm{a}}$ & $125.22 \pm 8.84^{c}$ & $6.45 \pm 2.93^{b}$ & $14.19 \pm 10.14^{b}$ & $2.79 \pm 1.23^{a}$ \\
\hline Ferulic acid (peak area) & $0.89 \pm 0.44^{c}$ & $79.31 \pm 3.22^{d}$ & $0.39 \pm 0.37^{b}$ & $0.68 \pm 1.18^{c}$ & $0.0040 \pm 0.0010^{a}$ \\
\hline Isoferulic acid (peak area) & $4.92 \pm 1.68^{a}$ & $33.24 \pm 0.44^{d}$ & $12.77 \pm 2.56^{c}$ & $8.68 \pm 0.28^{b}$ & - \\
\hline
\end{tabular}

Each value is expressed as mean \pm SD $(n=3)$. Means values with different superscripts in the same row are significantly different $(p<0.05)$, while with same superscripts are not signifiacntly different $(p>0.05)$. PERC, petroleum ether extract of rhizoma Cimicifugae; EARC, ethyl acetate extract of rhizoma Cimicifugae; $A E R C$, absolute ethanol extract of rhizoma Cimicifugae; 95ERC, 95\% ethanol extract of rhizoma Cimicifugae; WRC, water extract of rhizoma Cimicifugae. -: Below the detection limit. Pyr., pyrogallo; Ole., Oleanic acid.

\section{Superoxide anion $\left(\cdot \mathrm{O}_{2}^{-}\right)$radical-scavenging assay}

Measurement of superoxide anion $\left(\bullet \mathrm{O}_{2}^{-}\right)$scavenging activity was based on our method [27]. Briefly, samples were dissolved in methanol at $3 \mathrm{mg} / \mathrm{mL}$. The sample solution $x \mu \mathrm{L}(x=67,117,167,217,267$, and 317) was mixed with Tris-HCl buffer $(2950-x \mu \mathrm{L}, 0.05 \mathrm{M}, \mathrm{pH}$ 8.2) containing EDTA $(1 \mathrm{mM})$ and pyrogallol $(50 \mu \mathrm{L}$, $6 \mathrm{mM}$ in $10.0 \mathrm{mM} \mathrm{HCl}$ ), then shaken rapidly at $37^{\circ} \mathrm{C}$. The absorbance at $325 \mathrm{~nm}$ of the mixture was measured (Unico 2100, Shanghai, China) against the Tris-HCl buffer as blank every $30 \mathrm{~s}$ for $5 \mathrm{~min}$. The slope of the correlation of absorbance with time was calculated. The reaction mixture without sample was used as the control. The $\bullet \mathrm{O}_{2}^{-}$ scavenging ability was calculated as:

$$
\left(\frac{\Delta A_{325 n m, \text { control }}}{T}-\frac{\Delta A_{325 n m, \text { sample }}}{T}\right) / \frac{\Delta A_{325 n m, \text { control }}}{T} \times 100 \%
$$

Here, $\Delta A_{325 n m}$, control is the increase in $A_{325 n m}$ of the mixture without the sample and $\Delta A_{325 n m}$, sample is that for the mixture with the sample; $T=5 \mathrm{~min}$. The experiment temperature was $37^{\circ} \mathrm{C}$.

\section{Chelating activity on $\mathrm{Cu}^{2+}$}

The $\mathrm{Cu}^{2+}$-chelating activities of five $\mathrm{RC}$ extracts were measured by the method [28]. Briefly, $60 \mu \mathrm{L} \mathrm{CuSO}_{4}$. aqueous solution $(20 \mathrm{mM})$ was added to hexamine $\mathrm{HCl}$ buffer ( $\mathrm{pH} 5.3,30 \mathrm{mM}$ ) containing $30 \mathrm{mM} \mathrm{KCl}$ and $0.20 \mathrm{mM}$ murexide. After incubation for $1 \mathrm{~min}$ at room temperature, $80-230 \mu \mathrm{L}$ sample solutions $(4 \mathrm{mg} / \mathrm{mL}$ in methanol) were added. The final volume was adjusted to $1500 \mu \mathrm{L}$ with methanol. Then, the mixture was shaken vigorously and left at room temperature for $10 \mathrm{~min}$. Absorbance of the solution was then measured by a spectrophotometer (Unico 2100, Shanghai, China) at $485 \mathrm{~nm}$ and $520 \mathrm{~nm}$. The absorbance ratio $\left(A_{485} / A_{520}\right)$ reflected the free $\mathrm{Cu}^{2+}$ content. Therefore, the percentage of cupric chelating effect was calculated by the following formula:

$$
\text { Relative chelating effect } \%=\frac{\left(\frac{A_{485}}{A_{520}}\right)_{\max }-\left(\frac{A_{485}}{A_{520}}\right)}{\left(\frac{A_{485}}{A_{520}}\right)_{\max }-\left(\frac{A_{485}}{A_{520}}\right)_{\min }} \times 100 \%
$$

Where $\left(\frac{A_{485}}{A_{520}}\right)$ is the absorbance ratio of the sample, while $\left(\frac{A_{485}}{A_{520}}\right)_{\max }$ is the maximum absorbance ratio and $\left(\frac{A_{485}}{A_{520}}\right)_{\text {min }}$ is the minimum absorbance ratio in the test.

\section{$D P P H \cdot$ scavenging assay}

$\mathrm{DPPH}$ - radical-scavenging activity was determined as previously described by Li [23]. Briefly, $0.8 \mathrm{~mL} \mathrm{DPPH}$ •

\begin{tabular}{|c|c|c|c|c|c|c|}
\hline & Total phenolics & Caffeic acid & Ferulic acid & Isoferulic acid & Total sugars & Total saponins \\
\hline Anti-LPO & 0.99 & 0.98 & 0.96 & 0.95 & -0.69 & -0.001 \\
\hline DNA & 0.61 & 0.38 & 0.37 & 0.40 & -0.11 & -0.35 \\
\hline$\cdot \mathrm{OH}$ & 0.57 & 0.37 & 0.34 & 0.47 & 0.11 & -0.68 \\
\hline$\cdot \mathrm{O}_{2}^{-}$ & 0.36 & 0.38 & 0.33 & 0.53 & -0.53 & 0.14 \\
\hline Chelating & 0.17 & 0.31 & 0.31 & 0.21 & -0.88 & 0.94 \\
\hline DPPH• & 0.43 & 0.39 & 0.35 & 0.35 & 0.46 & -0.92 \\
\hline ABTS. ${ }^{+}$ & 0.57 & 0.54 & 0.61 & 0.49 & 0.30 & -0.84 \\
\hline Reducing & 0.82 & 0.65 & 0.68 & 0.68 & -0.26 & -0.39 \\
\hline Average & 0.56 & 0.51 & 0.50 & 0.51 & -0.20 & -0.26 \\
\hline
\end{tabular}

Table 3 The $R$ values between chemical contents and $1 / \mathbf{C C}_{50}$

$\mathrm{R}$, correlation coefficient; $1 / \mathrm{IC} \mathrm{C}_{50}$ : the unit is $\mathrm{mL} / \mu \mathrm{g}$, all $1 / \mathrm{IC} \mathrm{C}_{50}$ values are listed in Additional file 2 . LPO, lipid peroxidation. 


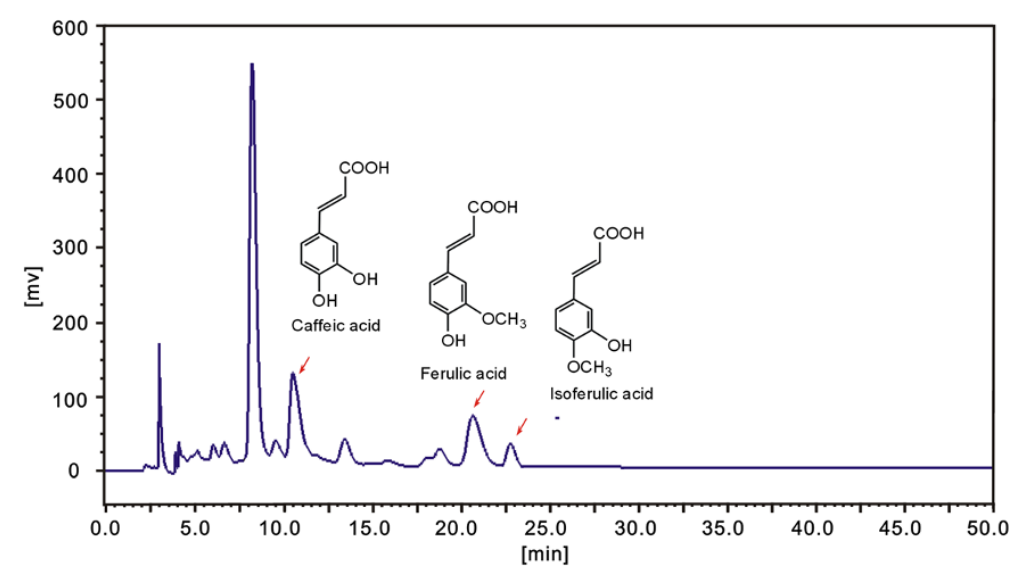

Figure 1 A typical HPLC profile of EARC (ethyl acetate extract of rhizoma Cimicifugae). Syltech P510 HPLC system (Los Angeles, California, USA), Dikma Diamonsil $C_{18}(250 \mathrm{~mm} \times 4.6 \mathrm{~mm}, 5 \mu \mathrm{m}$ size) (Beijing, China), acetonitrile- $0.5 \%$ acetic acid in water (17:83, v: v), $1.0 \mathrm{~mL} / \mathrm{min}$ flow rate, $30 \mu \mathrm{L}$ injection, $316 \mathrm{~nm}$ wavelength.

solution $(0.1 \mathrm{M})$ was mixed with $4.2 \mathrm{~mL}$ various concentrations $(15-300 \mu \mathrm{g} / \mathrm{mL})$ of samples dissolved in $95 \%$ ethanol. The mixture was kept at room temperature for $30 \mathrm{~min}$, and then measured with a spectrophotometer (Unico 2100, Shanghai, China) at $519 \mathrm{~nm}$. The DPPH. inhibition percentage of the samples was calculated:

Inhibition $\%=\frac{A_{0}-A}{A_{0}} \times 100 \%$
Where $A_{O}$ is the absorbance without samples, while $A$ is the absorbance with samples.

\section{ABTS. ${ }^{+}$scavenging assay}

The ABTS $\bullet^{+}$-scavenging activity was measured as described [23] with some modifications. The ABTS $\bullet^{+}$ was produced by mixing $0.35 \mathrm{~mL}$ ABTS diammonium salt $(7.4 \mathrm{mM})$ with $0.35 \mathrm{~mL}$ potassium persulfate $(2.6 \mathrm{mM})$. The mixture was kept in the dark at room

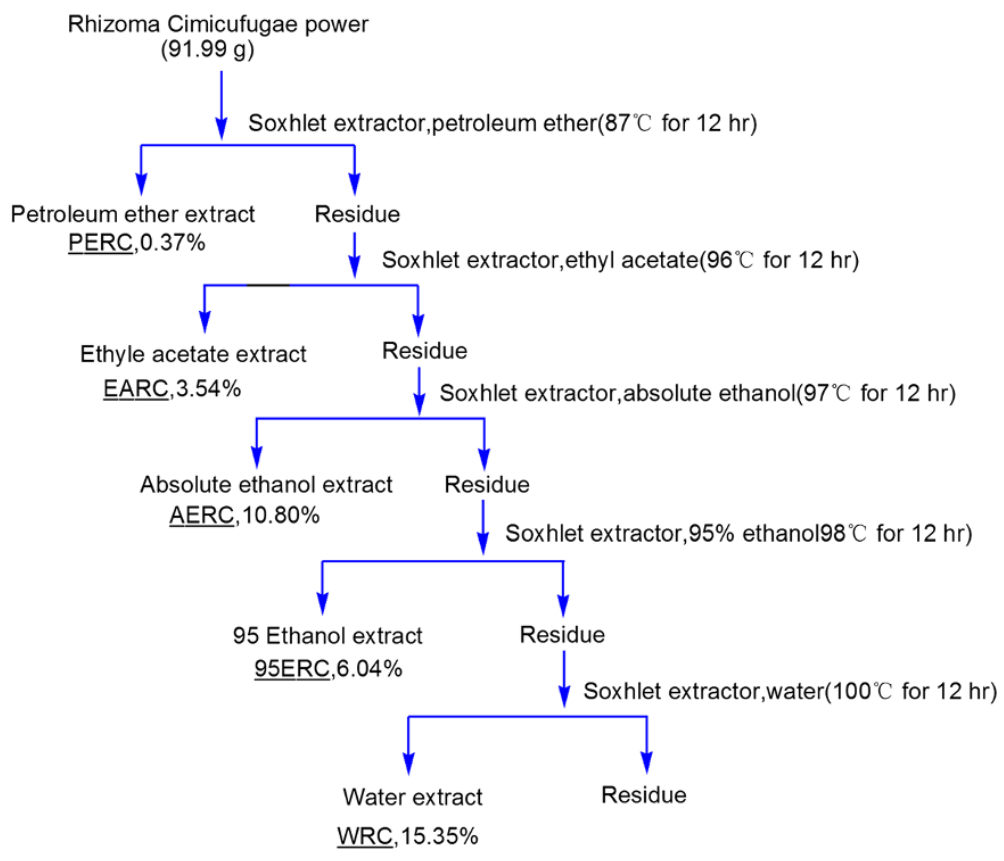

Figure 2 Preparation of five extracts of rhizoma Cimicifugae. 
temperature for 12 hours to allow completion of radical generation, then diluted with 95\% ethanol (about 1:50) so that its absorbance at $734 \mathrm{~nm}$ was $0.70 \pm 0.02$. To determine the scavenging activity, $1.2 \mathrm{~mL}$ aliquot of ABTS ${ }^{+}$reagent was mixed with $0.3 \mathrm{~mL}$ of sample ethanolic solutions $(40-540 \mu \mathrm{g} / \mathrm{mL})$. After incubation for $6 \mathrm{~min}$, the absorbance at $734 \mathrm{~nm}$ was read on a spectrophotometer (Unico 2100, Shanghai, China). The percentage inhibition of the samples was calculated as:

$$
\text { Inhibition } \%=\frac{A_{0}-A}{A_{0}} \times 100 \%
$$

Where $A_{O}$ is the absorbance at $734 \mathrm{~nm}$ without samples, while $A$ is the absorbance at $734 \mathrm{~nm}$ with samples.

\section{Reducing power $\left(\mathrm{Fe}^{3+}\right)$ assay}

Ferric cyanide $\left(\mathrm{Fe}^{3+}\right)$ reducing power was determined according to the method of Oyaizu [23,29]. In brief, sample solutions $x \mu \mathrm{L}(4 \mathrm{mg} / \mathrm{mL}, x=20,40,60,80$, and 100) were mixed with $(350-x) \mu \mathrm{L} \mathrm{Na} \mathrm{NPO}_{4} / \mathrm{KH}_{2} \mathrm{PO}_{4}$ buffer (0.2 M, pH 6.6) and $250 \mu \mathrm{L} \mathrm{K}_{3} \mathrm{Fe}(\mathrm{CN})_{6}$ aqueous solution (1 g/100 mL).

The mixture was incubated at $50^{\circ} \mathrm{C}$ for $20 \mathrm{~min}, 250 \mu \mathrm{L}$ of trichloroacetic acid $(10 \mathrm{~g} / 100 \mathrm{~mL})$ was added, and the mixture was centrifuged at $3500 \mathrm{r} / \mathrm{min}$ for $10 \mathrm{~min}$. As soon as $400 \mu \mathrm{L}$ supernatant was mixed with $400 \mu \mathrm{L}$ $\mathrm{FeCl}_{3}(0.1 \mathrm{~g} / 100 \mathrm{~mL}$ in distilled water $)$, the timer was started. At $90 \mathrm{~s}$, absorbance of the mixture was read at $700 \mathrm{~nm}$ (Unico 2100, Shanghai, China). Samples were analyzed in groups of three, and when the analysis of one group has finished, the next group of three samples were mixed with $\mathrm{FeCl}_{3}$ to prevent the mixture from being oxidized by air. The relative reducing ability of the sample was calculated by using the formula:

$$
\text { Relative reducing effect } \%=\frac{A-A_{\min }}{A_{\max }-A_{\min }} \times 100 \%
$$

Here, $A_{\max }$ is the maximum absorbance and $A_{\min }$ is the minimum absorbance in the test. $A$ is the absorbance of sample.

\section{HPLC analysis for caffeic acid, ferulic acid, and isoferulic acid}

Caffeic acid, ferulic acid, and isoferulic acid were identified by comparing their retention times using HPLC method. HPLC analysis was performed on a Syltech P510 system (Los Angeles, California, USA) equipped with Dikma Diamonsil $\mathrm{C}_{18}(250 \mathrm{~mm} \times 4.6 \mathrm{~mm}, 5 \mu \mathrm{m})$ (Beijing, China). The mobile phase consisted of acetonitrile- $0.5 \%$ acetic acid in water $(17: 83, \mathrm{v}: \mathrm{v})$, the flow rate was $1.0 \mathrm{~mL} / \mathrm{min}$, injection volume was $30 \mu \mathrm{L}$ and absorption was measured at $316 \mathrm{~nm}$.

\section{Determination of total phenolics, total sugars and total saponins}

The total phenolics of five $\mathrm{RC}$ extracts were determined by the Folin-Ciocalteu method with a little modifications [30]. Firstly, $0.5 \mathrm{~mL}$ extract methanolic solution $(0.4 \mathrm{mg} / \mathrm{mL}$ ) was mixed with $0.5 \mathrm{~mL} 0.25 \mathrm{M}$ Folin-Ciocalteu reagent. After incubation for $3 \mathrm{~min}, 1 \mathrm{~mL}$ of $\mathrm{Na}_{2} \mathrm{CO}_{3}$ solution $(15 \%, w / v)$ was added. After standing at the room temperature for $30 \mathrm{~min}$, the mixture was centrifuged at $3500 \mathrm{r} / \mathrm{min}$ for $3 \mathrm{~min}$. The absorbance of the supernatant was measured at $760 \mathrm{~nm}$ (Unico 2100, Shanghai, China). The determinations were performed in triplicate, and the calculations were based on a calibration curve obtained with pyrogallol. The result was expressed as pyrogallol equivalents (Pyr.) in milligrams per gram of extract.

The total sugars were evaluated according to the phenol-sulfuric acid method [30]. A 40- $\mu \mathrm{L}$ aliquot of sample solution $(1 \mathrm{mg} / \mathrm{mL})$ was placed in a flask, then $210 \mu \mathrm{L}$ distilled water, $250 \mu \mathrm{L}$ phenol solution (5\%, w/v) and $250 \mu \mathrm{L}$ concentrated sulfuric acid were added. After incubation for $20 \mathrm{~min}$ at room temperature, the absorbance of reaction mixture was measured at $490 \mathrm{~nm}$ (Unico 2100, Shanghai, China). The measurements were performed in triplicate, and the calculations were based on a calibration curve obtained with glucose. The result was expressed as glucose equivalents in milligrams per gram of extract.

The total saponins were measured according to the method [30]. RC extract was dissolved in methanol to prepare the sample solution $(4 \mathrm{mg} / \mathrm{mL})$, then a $20-\mu \mathrm{L}$ aliquot of sample solution was taken into a mini tube. After the sample solution in tube was evaporated to dryness (water bath, $80^{\circ} \mathrm{C}$ ), $0.1 \mathrm{~mL}$ vanillin-acetic acid solution $(5 \mathrm{mg} / \mathrm{mL})$ and $0.4 \mathrm{~mL}$ perchloric acid were added to the sample residue. The reaction mixture was incubated at $70^{\circ} \mathrm{C}$ for $15 \mathrm{~min}$, then diluted by $1.25 \mathrm{~mL}$ acetic acid. The mixture was measured using a spectrophotometer (Unico 2100, Shanghai, China) at $540 \mathrm{~nm}$ against a blank control, which contained all reagents except sample. All analyses were run in triplicate. Quantification was based on the standard curve for oleanic acid (10-79 $\mu \mathrm{g} / \mathrm{mL})$ and the results were expressed in milligrams of oleanic acid (Ole.) equivalents per gram of extract.

\section{The correlation graphs and $R$ values}

In order to investigate the correlation between antioxidant activities and chemical components of five RC extracts, 48 correlation graphs were plotted between $1 / \mathrm{IC}_{50}$ values (including of LPO, DNA, $\bullet \mathrm{OH}, \mathrm{O}_{2}^{-}, \mathrm{Cu}$-chelating, $\mathrm{DPPH} \bullet, \mathrm{ABTS}_{\bullet}{ }^{+}$, and reducing power assays) and chemical contents (including total phenolics, caffeic acid, ferulic acid, isoferulic acid, total sugars, and total saponins). In the correlation graphs, the correlation coefficients ( $R$ values) were calculated by Origin 6.0 professional software. 


\section{Statistical analysis}

Data are given as the mean \pm SD of three measurements. The $\mathrm{IC}_{50}$ values were calculated by linear regression analysis. All linear regression in this paper was analyzed by Origin 6.0 professional software. Significant differences were performed using the $T$-test $(p<0.05)$. The analysis was performed using SPSS software (v.12, SPSS, USA).

\section{Conclusion}

As an effective antioxidant, rhizoma Cimicifugae can protect DNA and lipids against oxidative damage. Its antioxidant ability can be responsible for its various pharmacological effects and may be mainly attributed to the existence of total phenolics, among which caffeic acid, ferulic acid and isoferulic acid are regarded as main bioactive components. Rhizoma Cimicifugae exerts its antioxidant effect through metal-chelating, and radicalscavenging which is via donating hydrogen atom $(\mathrm{H} \bullet)$ and donating electron (e).

\section{Additional files}

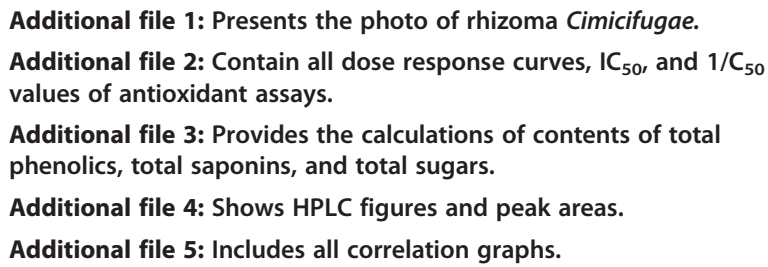

\section{Abbreviations}

RC: Rhizoma Cimicifugae; PERC: Petroleum ether extract from rhizoma Cimicifugae; EARC: Ethyl acetate extract from rhizoma Cimicifugae; AERC: Absolute ethanol extract from rhizoma Cimicifugae; 95ERC: 95\% ethanol extract from rhizoma Cimicifugae; WRC: Water extract from rhizoma Cimicifugae; DPPH•: 1,1-diphenyl-2-picryl-hydrazl radical; ABTS: 2,2'-azino-bis (3-ethylbenzo- thiazoline-6-sulfonic acid salt); ROS: Reactive oxygen species; TCM: Traditional Chinese medicine; BHT: 2,6-di-tert-butyl-4-methyphenol; GSH: Glutathione; BHA: Butylated hydroxyanisole; TBARS: Thiobarbituric acid reactive substances; TBA: Thiobarbituric acid; MDA: Malondialdehyde.

\section{Competing interests}

The authors declare that they have no competing interests.

\section{Authors' contribution}

$X L \& J L$ made a significant contribution to experiment design, acquisition of data, analysis, drafting of the manuscript. YG and WH have made a substantial contribution to interpretation of data, drafting. DC has carefully revised the manuscript for intellectual content. All authors read and approved the final manuscript.

\section{Acknowledgement}

This work was supported by the National Nature Science Foundation of China (81273896) and National Key Technologies R\&D Program of China (No. 2008BAI51B01).

Received: 30 September 2012 Accepted: 12 November 2012 Published: 23 November 2012

\section{References}

1. Leichert LI, Gehrke F, Gudiseva HV, Blackwell T, Ilbert M, Walker AK, Strahler JR, Andrews PC, Jakob U: Quantifying changes in the thiol redox proteome upon oxidative stress in vivo. Proc Natl Acad Sci USA 2008, 105:8197-8202

2. Halliwell B, Gutteridge JM: Oxygen toxicity, oxygen radicals, transition metals and disease. Biochem J 1984, 219:1-14

3. Bhattacharjee $S$, Deterding $L$, Chatterjee $S$, Jiang J, Ehrenshaft M, Lardinois $\mathrm{O}$, Ramirez DC, Tomer KB, Mason RP: Site-specific radical formation in DNA induced by $\mathrm{Cu}(\mathrm{II})-\mathrm{H}_{2} \mathrm{O}_{2}$ oxidizing system, using $\mathrm{ESR}$, immuno-spin trapping, LC-MS, and MS/MS. Free Radic Biol Med 2011, 50:1536-1545.

4. Tao HJ: Variorum of Shennong's Classic of Materia Medica. Beijing: People's Medical Publishing House; 1995:45.

5. Chinese Pharmacopoeia Commission: The Pharmacopoeia of Chinese People's Republic. Beijing China: Chemical Industry Publishing House; 2005:50.

6. Ye L, Hu Z, Du G, Zhang J, Dong Q, Fu F, Tian J: Antidepressant-like effects of the extract from Cimicifuga foetida L. J Ethnopharmacol in press. doi:10.1016/j.jep.2012.10.013.

7. Kim SJ, Kim MS: Inhibitory effects of Cimicifugae rhizoma extracts on histamine, bradykinin and COX-2 mediated inflammatory actions. Phytother Res 2000, 14:596-600

8. Nisslein T, Freudenstein J: Effects of an isopropanolic extract of Cimicifuga racemosa on urinary crosslinks and other parameters of bone quality in an ovariectomized rat model of osteoporosis. J Bone Miner Metab 2003, 21:370-376.

9. Ahn BS, Yang M, Jang H, Lee HJ, Moon C, Kim JC, Jung U, Jo SK, Jang JS, Kim SH: Evaluation of the antiosteoporotic potential of Cimicifuga heracleifolia in female mice. Phytother Res 2012, 26:663-668.

10. Kim M: Protective effect of Cimicifuga heracleifolia ethanol extract and its constituents against gastric injury. J Health Sci 2011, 3:289-292.

11. Zheng RL, Huang $Z Y$ : The definition and characteristic of free radicals. In Free Radical Biology, Volume 1. Edited by Huang ZY, Zheng RL. Beijing China: Chinese Higher Education Press; 2007:7.

12. Dizdaroglu M, Jaruga $P$, Birinciolgu $M$, Rodriguez H: Free radical-induced damage to DNA: mechanism and measurement. Free Radic Biol Med 2002, 32:1102-1115

13. Keyer K, Imlay JA: Superoxide accelerates DNA damage by elevating free-iron levels. Proc Natl Acad Sci USA 1996, 93:13635-13640.

14. Han WJ, Li XC: Antioxidant activity of aloeswood tea in vitro. Spatula DD 2012, 2:43-50

15. Torreggiani A, Tamba M, Trinchero A, Bonora S: Copper (II)-quercetin complexes in aqueous solutions: spectroscopic and kinetic properties. J Mol Struct 2005, 280:759-766.

16. Bondet V, Brand-Williams W, Berset C: Kinetics and mechanisms of antioxidant activity using the DPPH free radical method. LWT- Food Sci Technol 1997, 30:609-615.

17. Brand-Williams W, Cuvelier ME, Berset C: Use of free radical method to evaluate antioxidant activity. LWT- Food Sci Technol 1995, 28:25-30

18. Tsimogiannis DI, Oreopoulou V: The contribution of flavonoid C-ring on the DPPH free radical scavenging efficiency. A kinetic approach for the 3', 4'-hydroxy substituted members. Innov Food Sci Emerg 2006, 7:140-146.

19. Saito S, Kawabata J: Effects of electron-withdrawing substituents on DPPH radical scavenging reactions of protocatechuic acid and its analogues in alcoholic solvents. Tetrahedron 2005, 61:8101-8108.

20. Prior RL, Cao G: In vivo total antioxidant capacity: comparison of different analytical methods. Free Radic Biol Med 1999, 27:1173-1181.

21. Liu BB, Chen SH, Chen SB: The chemical composition and research progress of anti-tumor activity of Cimicifuga. Cent South Phar 2012, 10:53-58.

22. Gülçin I: Antioxidant activity of caffeic acid (3,4-dihydroxycinnamic acid). Toxicology 2006, 217:213-220.

23. Wang XZ, Li XC, Chen DF: Evaluation of antioxidant activity of isoferulic acid in vitro. Nat Prod Commun 2011, 6:1285-1288.

24. Li XC, Wu XT, Huang L: Correlation between antioxidant activities and phenolic contents of Radix Angelica Sinensis (Danggui). Molecules 2009, 14:5349-5361

25. Wang XZ, Li XC, Li HR: Reassessment of antioxidant activity of baicalein in vitro. Asian J Pharm Biol Res 2011, 1:186-194.

26. Li XC, Chen C: Systematic evaluation on antioxidant of magnolol in vitro. Int Res J Pure Appl Chem 2012, 2:68-76.

27. Li XC: Improved pyrogallol autoxidation method: a reliable and cheap superoxide-scavenging assay suitable for all antioxidants. J Agric Food Chem 2012, 60:6418-6424. 
28. Li XC, Wang XZ, Chen DF, Chen SZ: Antioxidant activity and mechanism of protocatechuic acid in vitro. Funct Food Health Dis 2011, 1:232-244.

29. Oyaizu M: Studies on product of browning reaction prepared from glucoseamine. Jpn J Nutr 1986, 44:307-315.

30. Li XC, Chen DF, Mai Y, Wen B, Wang XZ: Concordance between antioxidant activities in vitro and chemical components of Radix Astragali (Huangqi). Nat Prod Res 2012, 26:1050-1053.

doi:10.1186/1752-153X-6-140

Cite this article as: Li et al:: Antioxidant activity and mechanism of

Rhizoma Cimicifugae. Chemistry Central Journal 2012 6:140.

\section{Publish with ChemistryCentral and every scientist can read your work free of charge}

"Open access provides opportunities to our colleagues in other parts of the globe, by allowing anyone to view the content free of charge."

W. Jeffery Hurst, The Hershey Company.

- available free of charge to the entire scientific community

- peer reviewed and published immediately upon acceptance

- cited in PubMed and archived on PubMed Central

- yours - you keep the copyright

Submit your manuscript here:

Submit your manuscript here:
http://www.chemistrycentral.com/manuscript/<smiles>c1ccccc1</smiles> 